\title{
Mill Scale for Synthesis of Fe-Ni and Fe-Ni-Co Alloys through Gaseous Reduction: Reaction Kinetics and Mechanism
}

\author{
M. BAHGAT, ${ }^{1)}$ Min-Kyu PAEK ${ }^{2)}$ and Jong-Jin PAK ${ }^{21}$ \\ 1) Formally Minerals Technology Department, Central Metallurgical Research and Development Institute (CMRDI), Cairo, \\ Egypt. Now at Department of Metallurgical and Materials Engineering, Hanyang University, Ansan, Korea. \\ 2) Department of Metallurgical and Materials Engineering, Hanyang University, Ansan 426-791, Korea. \\ E-mail: jjpark@hanyang.ac.kr
}

(Received on May 2, 2008; accepted on July 25, 2008)

\begin{abstract}
Nickel and Nickel cobalt ferrite powders were prepared through the ceramic route by calcination of a stoichiometric mixture of nickel oxide, cobalt oxide and mill scale as source for iron oxide. The produced ferrites powders were isothermally reduced in pure hydrogen at $800-1100^{\circ} \mathrm{C}$. Based on thermogravimetric analysis, the reduction behavior of the synthesized ferrite and the kinetics reaction mechanism were studied. The initial ferrite powder and the various reduction products were characterized by XRD, SEM and reflected light microscope to reveal the effect of hydrogen reduction on composition, microstructure and reaction kinetics of synthesized ferro-alloys. The activation energy values were calculated from Arrhenius equation. The approved mathematical formulations for the gas solid reaction were applied to confirm the estimated rate controlling reaction mechanism. Complete reduction of home made ferrite powder was achieved with synthesize of nanocrystalline $\mathrm{Fe}-\mathrm{Ni}$ and $\mathrm{Fe}-\mathrm{Ni}-\mathrm{Co}$ alloys.
\end{abstract}

KEY WORDS: mill scale; nickel ferrite; nickel cobalt ferrite; $\mathrm{H}_{2}$-reduction; nanocrystallites; Fe-Ni; Fe-Ni-Co alloy; reduction kinetics.

\section{Introduction}

Iron and steel-making process is one of the most important industrial manufacturing processes. Actually, day after day many requirements are created for this type of industry. This is owing to the problems that related to the most critical factors of this industry which are resources, energy and environment. The produced $\mathrm{CO}_{2}$ is the major component of the greenhouse gases, which caused the global warming. So, establishment and development of a new fundamental technology in this industry become an urgent at these moments. The hydrogen reduction route provides an excellent alternative toward the possibility of using green energy for development of economically viable and environmentally friendly processes to meet the growing industrial needs. ${ }^{1)}$

On the other hand, about $90 \%$ of world ferro-alloy production is consumed by the steel industry. These alloys are essential additives in steelmaking used for imparting desired properties to steel and so these alloys act as a means of introducing these alloying elements into the cast or as deoxidizers. Specialized applications for ferro-alloys also exist in fields such as semi-conductors, photovoltaic cells, chemicals manufacture and specialty ceramics. ${ }^{2,3)}$ Namely $\mathrm{Fe}-\mathrm{Ni}$ and $\mathrm{Fe}-\mathrm{Ni}-\mathrm{Co}$ alloys are of great interest due to their low thermal expansion, remarked magnetic properties, high mechanical and chemical properties, ${ }^{4-14)}$ With this great importance, soon we will face to the depletion of alloying elements such as Cr, Ni, Mo, V and so on. So much attention should be directed toward these resources deficient. There are several attempts to recover these elements from special steel dust or SUS sludge or slag. Thus, the present research can be carried out as one of the solution for the resource problem of alloying elements using a clean and economic route.

Reduction of ferrites is an important step in developing master alloys in steel production. The mechanism and kinetics of reduction of different ferrites such as ferrites of cobalt, zinc, strontium, barium and magnesium were investigated. ${ }^{15-20)}$ However reduction of $\mathrm{Ni}_{x} \mathrm{Co}_{1-x} \mathrm{Fe}_{2} \mathrm{O}_{4}$ as source for Ferro-alloys was handled very limited through some investigations. $^{21-23)}$

During the heating of steel slabs before rolling in the steel making process, their upper layer can be oxidized to iron oxide. This oxide called "mill scale", could be removed from the surface by a shower of water during the rolling of these slabs. This mill scale can be considered as a valuable secondary raw material according to its high iron content, low impurities and stable chemical composition. However, these materials produced in a form of fine powder, where its quantity is increasing rapidly with the current demand of increasing world steel production.

The present investigation handled an economic and clean route for the synthesis of ferro-alloys from a secondary iron oxide resource (mill scale). Ceramic method was used for preparation of $\mathrm{NiFe}_{2} \mathrm{O}_{4}$ and $\mathrm{NiCoFe}_{2} \mathrm{O}_{4}$ from a mixed mill scale with analytical grade $\mathrm{CoO}$ and $\mathrm{NiO}$. Under the effect 
of reaction temperature, the reduction behaviour and kinetics in hydrogen atmosphere with synthesis of $\mathrm{Fe}-\mathrm{Ni}$ and $\mathrm{Fe}-\mathrm{Ni}-\mathrm{Co}$ alloys was investigated.

\section{Experimental Procedures}

Mill scale samples with $74.1 \%$ total iron, $0.057 \% \mathrm{TiO}_{2}$, $0.957 \% \mathrm{MgO}, 0.6 \% \mathrm{SiO}_{2}, 0.18 \% \mathrm{CaO}, 0.357 \% \mathrm{P}_{2} \mathrm{O}_{5}, 0.873$ $\% \mathrm{Al}_{2} \mathrm{O}_{3}, 0.42 \% \mathrm{MnO}, 0.047 \% \mathrm{~S}, 0.246 \% \mathrm{Cr}_{2} \mathrm{O}_{3}$ and 0.028 $\% \mathrm{C}$ are obtained from POHANG IRON \& STEEL Company (POSCO), South Korea. Mill scale fines $(<3 \mathrm{~mm})$ were firstly grinded to a very fine powder and then it is thoroughly mixed in calculated molar ratio with very fine $(1 \mu \mathrm{m})$ analytical reagent grade $(99.9 \%)$ nickel oxide and cobalt oxide for synthesis of $\mathrm{Ni}_{x} \mathrm{Co}_{1-x} \mathrm{Fe}_{2} \mathrm{O}_{4}(x=1,0.5)$ using agate mortar and dry ball milling technique for $6 \mathrm{~h}$. The well mixed oxides powder was dried at $105^{\circ} \mathrm{C}$ for $24 \mathrm{~h}$. Equal weights of dried powder were compressed into compacts of about $1.5 \mathrm{~g}$ weight, $7 \mathrm{~mm}$ diameter and $3 \mathrm{~mm}$ thickness. The prepared compacts were fired at $1000^{\circ} \mathrm{C}$ for $24 \mathrm{~h}$ then cooled to room temperature gradually.

The produced $\mathrm{Ni}_{x} \mathrm{Co}_{1-x} \mathrm{Fe}_{2} \mathrm{O}_{4}$ compacts were reduced at $800,900,1000$ and $1100^{\circ} \mathrm{C}$ in constant flowing hydrogen gas atmosphere. The course of reduction was followed up thermogravimetrically by means of a weight loss method using an automatic sensitive balance equipped with the vertical tube furnace.

The reduction extent is calculated as follow;

$$
\% \text { reduction }=\frac{\text { weight of } \mathrm{O}_{2} \text { removed at a given time }}{\text { weight of } \mathrm{O}_{2} \text { in } \mathrm{Ni}_{x} \mathrm{Co}_{1-x} \mathrm{Fe}_{2} \mathrm{O}_{4}} \times 100
$$

So the reduction extent was correlated to the total removable oxygen of ferrite powder. A gas purification system was used to obtain $99.99 \%$ purity hydrogen gas. The reduction assembly and gas flow system used in this study were previously mentioned. ${ }^{24)}$

In each experiment, after the furnace was heated up to the required temperature the ferrite compact was put inside a basket to be hanged in the balance and adjusted in the middle zone of the tube furnace in flow of purified Ar gas. After settling down for few minutes, the reducing gas was passed while the Ar gas was stopped. The reacted compact was kept in the reducing atmosphere till a constant weight was achieved. For cooling, the reducing gas was replaced by $\mathrm{Ar}$ and the reduced sample was pulled up at the upper part of the reaction tube and kept away from the hot zone. After the temperature became below $200^{\circ} \mathrm{C}$, the reduced compact was quenched in pure acetone. Preliminary reduction experiments showed that the most suitable hydrogen flow rate required to ensure an adequate supply of gas and overcome the gas boundary layer diffusion resistance, thus avoiding the gas starvation is $11 / \mathrm{min}$.

The synthesized $\mathrm{Ni}_{x} \mathrm{Co}_{1-x} \mathrm{Fe}_{2} \mathrm{O}_{4}$ powders and the reduced products were identified and characterized by X-ray phase analysis technique (XRD, High power X-ray Diffractometer System Rigaku D/MAX-2500/PC), High Resolution Field Emission scanning electron microscope (FE-SEM, Hitachi S4800), and optical microscope (Olympus PMG3).

\section{Results and Discussion}

\subsection{Characterization of Synthesized Nickel Ferrite Powder}

The ferrite powders $\left(\mathrm{NiFe}_{2} \mathrm{O}_{4}\right.$ and $\left.\mathrm{Ni}_{0.5} \mathrm{Co}_{0.5} \mathrm{Fe}_{2} \mathrm{O}_{4}\right)$ were successfully synthesized by the ceramic method using the mill scale. Figures 1(a) and 1(b) show the XRD pattern of

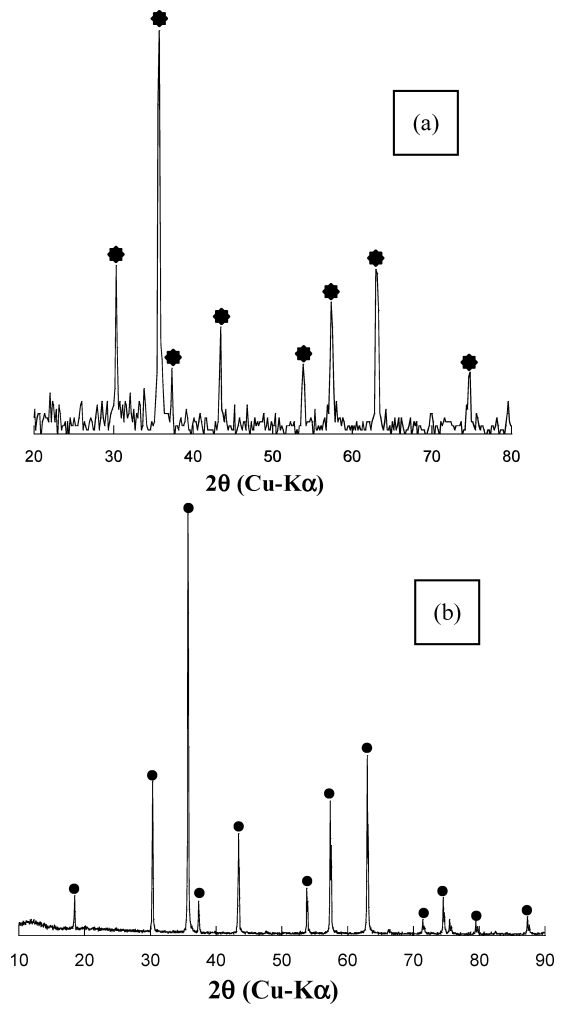

Fig. 1. $\mathrm{XRD}$ pattern for synthesized (a) $\mathrm{NiFe}_{2} \mathrm{O}_{4}$ and (b) $\mathrm{Ni}_{0.5} \mathrm{Co}_{0.5} \mathrm{Fe}_{2} \mathrm{O}_{4}$ Phase at $1000^{\circ} \mathrm{C}$.
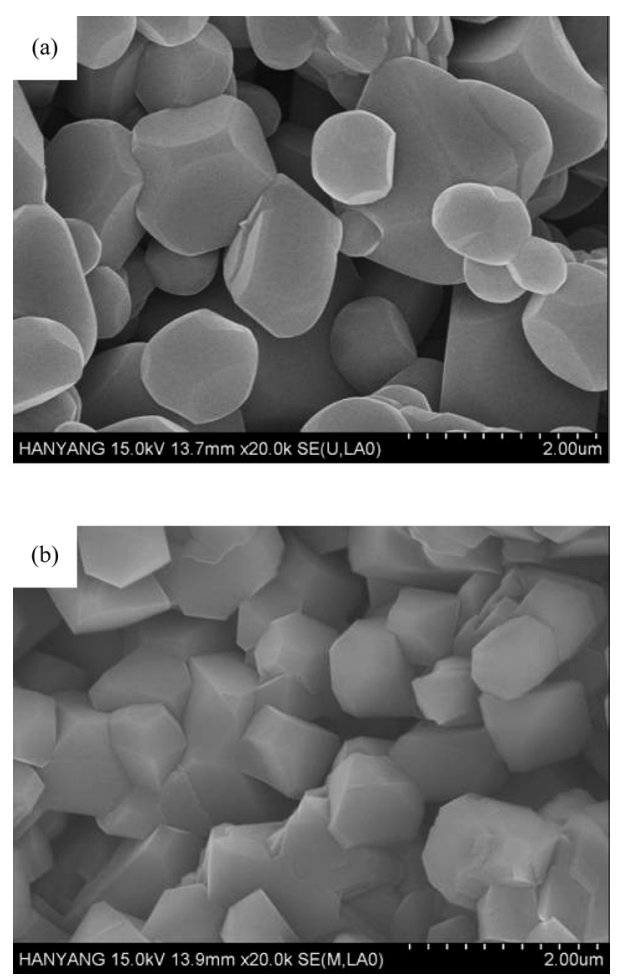

Fig. 2. SEM micrograph of synthesized (a) $\mathrm{NiFe}_{2} \mathrm{O}_{4}$ (b) $\mathrm{Ni}_{0.5} \mathrm{Co}_{0.5} \mathrm{Fe}_{2} \mathrm{O}_{4}$ ferrite. 
the synthesized ferrite powders whereas the sharp peaks reflected the good crystallinity of the formed phases. The SEM photos in Figs. 2(a) and 2(b) show the morphological observation of synthesized nickel ferrite $\left(\mathrm{NiFe}_{2} \mathrm{O}_{4}\right)$ and nickel cobalt ferrite $\left(\mathrm{Ni}_{0.5} \mathrm{Co}_{0.5} \mathrm{Fe}_{2} \mathrm{O}_{4}\right)$ powder respectively. It was observed that dense grains of ferrites are formed in a well regular crystalline shape as a matrix of small crystals. These grains are homogeneously distributed in the size range of $0.5-2.0 \mu \mathrm{m}$ for both of $\mathrm{NiFe}_{2} \mathrm{O}_{4}$ and $\mathrm{Ni}_{0.5} \mathrm{Co}_{0.5} \mathrm{Fe}_{2} \mathrm{O}_{4}$ with presence of macro-pores.

These phases were formed through a solid-state reaction between the mixed materials as follows:

$$
\begin{gathered}
\mathrm{NiO}+\mathrm{Fe}_{2} \mathrm{O}_{3}=\mathrm{NiFe}_{2} \mathrm{O}_{4} \\
\mathrm{NiO}+\mathrm{CoO}+2 \mathrm{Fe}_{2} \mathrm{O}_{3}=2 \mathrm{Ni}_{0.5} \mathrm{Co}_{0.5} \mathrm{Fe}_{2} \mathrm{O}_{4}
\end{gathered}
$$

The average crystallite size of the synthesized $\mathrm{NiFe}_{2} \mathrm{O}_{4}$ and $\mathrm{Ni}_{0.5} \mathrm{Co}_{0.5} \mathrm{Fe}_{2} \mathrm{O}_{4}$ powder was 37 and $54.4 \mathrm{~nm}$ respectively as calculated from $\mathrm{X}$-ray diffraction peaks using the following Scherer's formula, ${ }^{25)}$

$$
t=0.9 \lambda / B \cos \theta_{\mathrm{B}}
$$

Where $t$ is the crystallite size, $\lambda$ the $\mathrm{X}$-ray wave length, $B$ the angular width of the diffraction peak and $\theta$ is the diffraction angle.

\subsection{Reduction Behavior and Morphological Observa- tion}

Synthesized $\mathrm{NiFe}_{2} \mathrm{O}_{4}$ and $\mathrm{Ni}_{0.5} \mathrm{Co}_{0.5} \mathrm{Fe}_{2} \mathrm{O}_{4}$ compacts were isothermally reduced with pure $\mathrm{H}_{2}$ gas. Reduction was undertaken partially up to completion at different tempera-
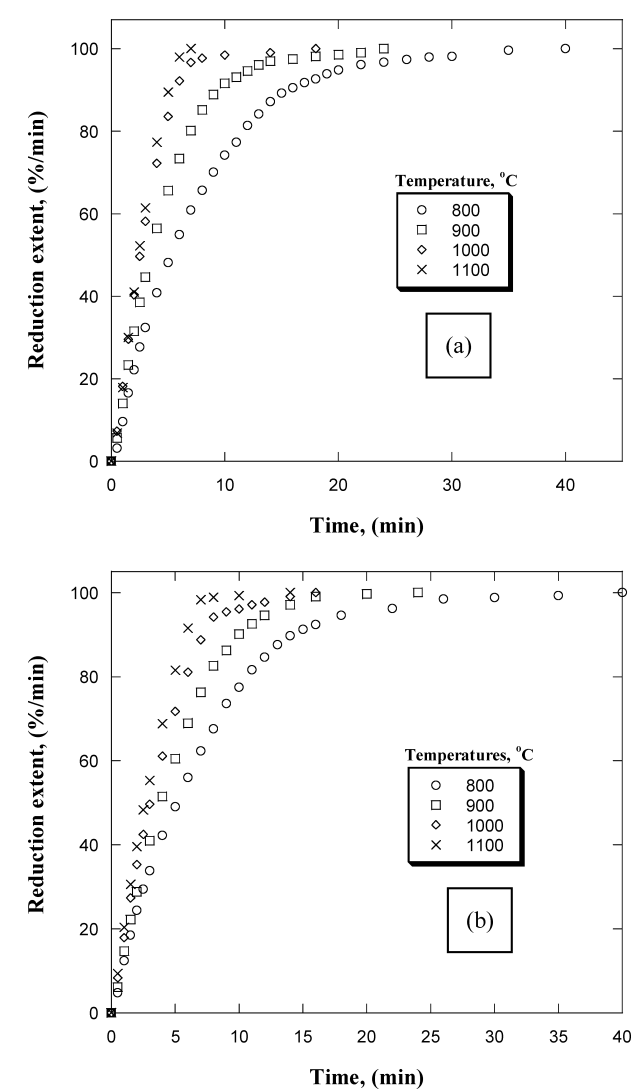

Fig. 3. Reduction curves of (a) $\mathrm{NiFe}_{2} \mathrm{O}_{4}$ and (b) $\mathrm{Ni}_{0.5} \mathrm{Co}_{0.5} \mathrm{Fe}_{2} \mathrm{O}_{4}$ compacts reduced at $800-1100^{\circ} \mathrm{C}$ with pure hydrogen gas. tures ranging from $800-1100^{\circ} \mathrm{C}$. The influence of reduction temperature on the structural characteristics of the products was extensively studied in order to get clear comprehension of reduction process. It was found that the temperature at which the reduction occurs has an effect on the reduction rate. The reduction curves for the prepared $\mathrm{NiFe}_{2} \mathrm{O}_{4}$ and $\mathrm{Ni}_{0.5} \mathrm{Co}_{0.5} \mathrm{Fe}_{2} \mathrm{O}_{4}$ compacts are given in Figs. 3(a) and 3(b). It can be seen that for each reduction curves, the rate of reduction was highest at early stage and gradually decreased with time till the end of experiment. The reduction rate increased as the reduction temperature increased either in the initial or final reaction stages and so the reaction time decreased gradually with increasing the reduction temperatures. Comparative reduction curves for $\mathrm{NiFe}_{2} \mathrm{O}_{4}$ and $\mathrm{Ni}_{0.5} \mathrm{Co}_{0.5} \mathrm{Fe}_{2} \mathrm{O}_{4}$ compacts at 900 and $1100^{\circ} \mathrm{C}$ are given in Fig. 4. It is observed that the reducibility of $\mathrm{NiFe}_{2} \mathrm{O}_{4}$ compacts is slightly faster than $\mathrm{Ni}_{0.5} \mathrm{Co}_{0.5} \mathrm{Fe}_{2} \mathrm{O}_{4}$

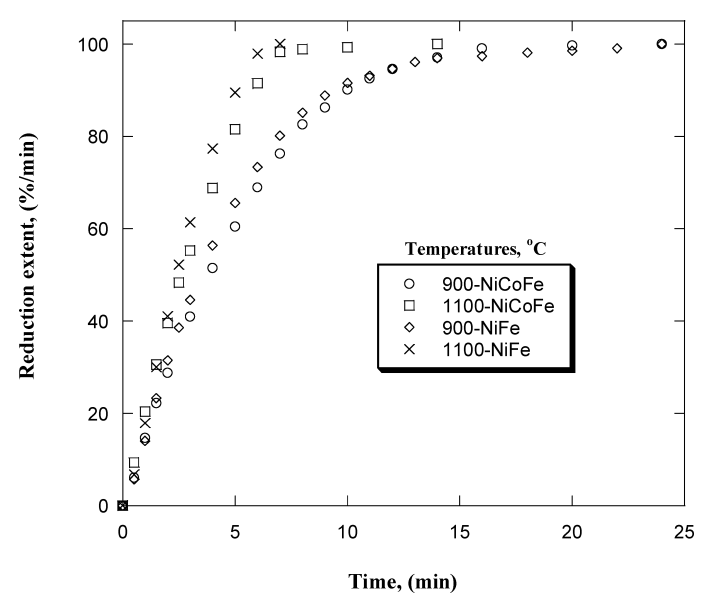

Fig. 4. Comparative reduction curves of $\mathrm{NiFe}_{2} \mathrm{O}_{4}$ and $\mathrm{Ni}_{0.5} \mathrm{Co}_{0.5} \mathrm{Fe}_{2} \mathrm{O}_{4}$ compacts at 900 and $1100^{\circ} \mathrm{C}$.

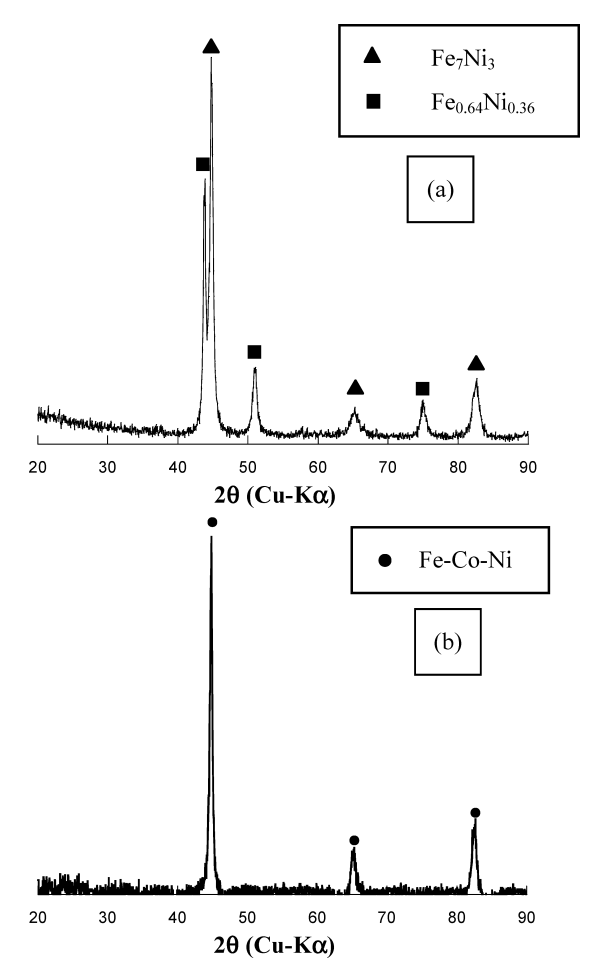

Fig. 5. XRD pattern of Synthesized (a) Fe-Ni and (b) Fe-Ni-Co alloys after reduction of fired compacts with hydrogen at $1100^{\circ} \mathrm{C}$. 


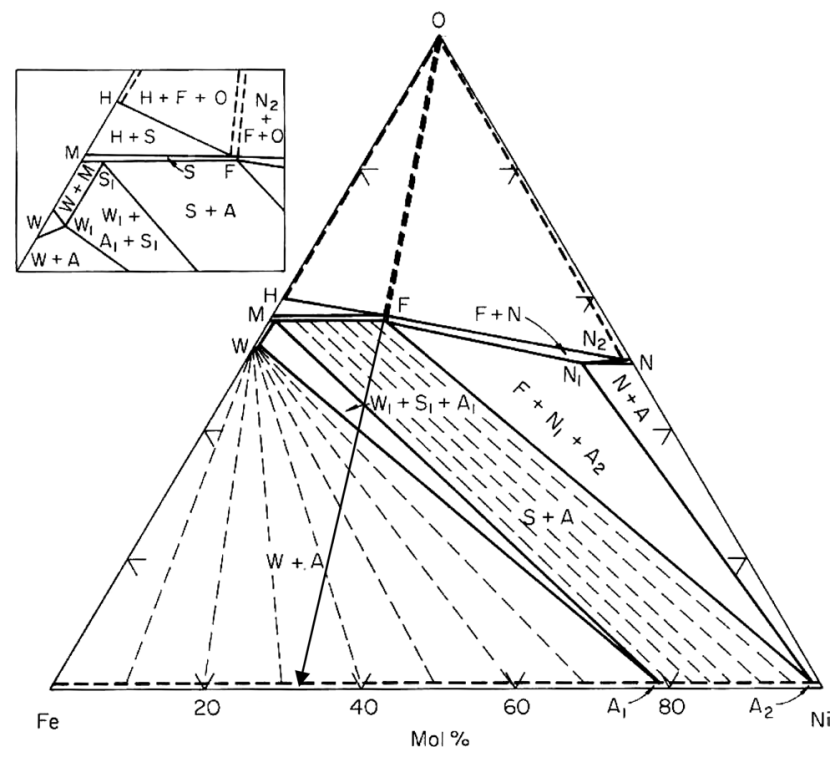

Fig. 6. System $\mathrm{Fe}-\mathrm{Ni}-\mathrm{O}$ at $1100^{\circ} \mathrm{C}$. $\mathrm{W}=$ wustite ("FeO"-NiO solid solutions); $\mathrm{N}=$ nikel oxide ( $\mathrm{NiO}-" \mathrm{FeO}$ " solid solutions); $\mathrm{S}=$ spinel $\left(\mathrm{Fe}_{3} \mathrm{O}_{4}-\mathrm{NiFe}_{2} \mathrm{O}_{4}\right.$ solid solution); $\mathrm{F}=$ nikel ferrite $\left(\mathrm{NiFe}_{2} \mathrm{O}_{4}\right) ; \mathrm{H}=$ hematite; $\mathrm{A}=$ alloy $(\mathrm{Fe}-\mathrm{Ni}$ solid solutions); $\mathrm{M}=$ magnetite $\left(\mathrm{Fe}_{3} \mathrm{O}_{4}\right)$.

compacts either at higher or lower reduction temperatures.

For both fired samples, complete reduction was achieved with synthesis of Fe-Ni and Fe-Ni-Co alloys as shown in Figs. 5(a) and 5(b) for the XRD pattern of reduction products.

$$
\begin{gathered}
\mathrm{NiFe}_{2} \mathrm{O}_{4}+4 \mathrm{H}_{2}=(\mathrm{Fe}, \mathrm{Ni})_{\mathrm{ss}}+4 \mathrm{H}_{2} \mathrm{O} \\
\mathrm{Ni}_{0.5} \mathrm{Co}_{0.5} \mathrm{Fe}_{2} \mathrm{O}_{4}+4 \mathrm{H}_{2}=(\mathrm{Fe}, \mathrm{Ni}, \mathrm{Co})_{\mathrm{ss}}+4 \mathrm{H}_{2} \mathrm{O}
\end{gathered}
$$

$\mathrm{Fe}-\mathrm{Ni}-\mathrm{O}$ phase diagram in Fig. $\mathbf{6}^{26)}$ is showing the reaction path of ferrite reduction into alloy.

The average crystallites size of synthesized nanocrystalline $\mathrm{Fe}-\mathrm{Ni}$ and $\mathrm{Fe}-\mathrm{Ni}-\mathrm{Co}$ alloys as depicted from XRD data are about 22 and $28 \mathrm{~nm}$ respectively. Also it was observed that the peaks of the synthesized ferro-alloy are strong and sharp revealing the high crystallinity of the particles.

Morphological observation of reduced nickel ferrite and nickel cobalt ferrite compacts using SEM is shown in Figs. 7(a) and 7(b). It is clearly seen that the Fe-Ni alloy were formed in two different shape structures that are homogenously distributed allover the sample. One is dense grains with irregular crystalline shape structure and the other is filament shape form of $50 \mathrm{~nm}$ thickness (Fig. 7(a)). The coalescence and sintering effect due to high reaction temperature was observed with presence of macro-pores. On the other hand, the synthesized $\mathrm{Fe}-\mathrm{Ni}-\mathrm{Co}$ alloy was formed with irregular crystalline shape grains in very dense structure whereas sever coalescence with sintering effect was obviously detected (Fig. 7(b)).

\subsection{Reduction Kinetics and Mechanisms}

Partial reduction of $\mathrm{NiFe}_{2} \mathrm{O}_{4}$ and $\mathrm{Ni}_{0.5} \mathrm{Co}_{0.5} \mathrm{Fe}_{2} \mathrm{O}_{4}$ compacts was carried out to 25 and $80 \%$ reduction extent to clarify the reduction progressing and mechanism investigating. The apparent activation energy $\left(E_{\mathrm{a}}\right)$ of reduction was calculated at both the initial and the final reaction stages to
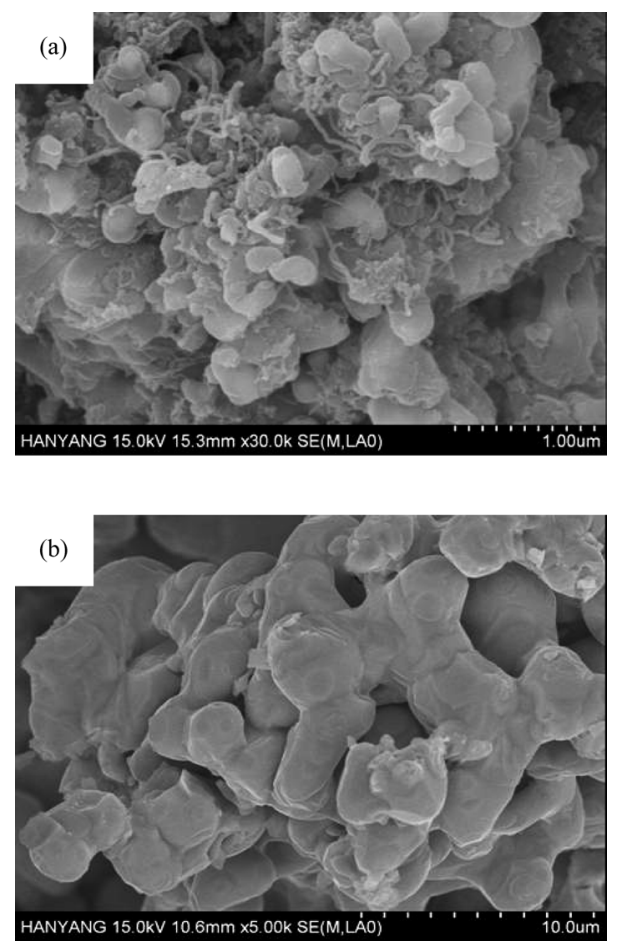

Fig. 7. SEM photos of Synthesized (a) Fe-Ni and (b) Fe-Ni-Co alloys after reduction of fired compacts with hydrogen at $1100^{\circ} \mathrm{C}$.

illustrate the rate controlling mechanism depending on Arrhenius equation;

$$
K_{\mathrm{r}}=K_{\mathrm{o}} e^{-E_{\mathrm{a}} / R_{\mathrm{g}} T}
$$

where $K_{\mathrm{r}}$ is the rate constant, $K_{\mathrm{o}}$ is the frequency factor, $R_{\mathrm{g}}$ is the gas constant and $T$ is the absolute temperature.

The relationships between the logarithm of the rate of reduction for nanocrystallites $\mathrm{NiFe}_{2} \mathrm{O}_{4}$ and $\mathrm{Ni}_{0.5} \mathrm{Co}_{0.5} \mathrm{Fe}_{2} \mathrm{O}_{4}$ compacts and the reciprocal of the absolute temperature are plotted at both the initial and latter stages as shown in Figs. 8(a) and 8(b). The calculated values of the apparent activation energy obtained from these relationships at the initial and final stages are 33 and $51.5 \mathrm{~kJ} / \mathrm{mol}$ for $\mathrm{NiFe}_{2} \mathrm{O}_{4}$ respectively. For $\mathrm{Ni}_{0.5} \mathrm{Co}_{0.5} \mathrm{Fe}_{2} \mathrm{O}_{4}$ the calculated $E_{\mathrm{a}}$ values at the initial and final reaction stages are 27.5 and $56.7 \mathrm{~kJ} / \mathrm{mol}$ respectively. The apparent activation energy values have been calculated by many investigators in order to determine the rate controlling step. ${ }^{27)}$ The calculated activation energy values indicate that the $\mathrm{NiFe}_{2} \mathrm{O}_{4}$ reduction at the initial and final reaction stages is controlled by the combined gas diffusion and interfacial chemical reaction mechanisms with high contribution for the interfacial chemical mechanism at the latter stages. Comparatively in the previous investigation for the authors ${ }^{23)}$ the $E_{\mathrm{a}}$ value at the final stage of the reduction of $\mathrm{NiFe}_{2} \mathrm{O}_{4}$ using chemical reagent is lower. In spite of the change in $E_{\mathrm{a}}$ value but they are belonging to the same reaction controlling mechanism. So this change might be owing to the presence of minor impurities in the mill scale that effect on the microstructure at the final reaction stages to facilitate the gas diffusion compared to the interfacial chemical reaction and so the $E_{\mathrm{a}}$ value is increased.

In case of $\mathrm{Ni}_{0.5} \mathrm{Co}_{0.5} \mathrm{Fe}_{2} \mathrm{O}_{4}$ reduction the initial reduction stage is controlled by the combined gas diffusion and interfacial chemical reaction mechanisms with more contribu- 

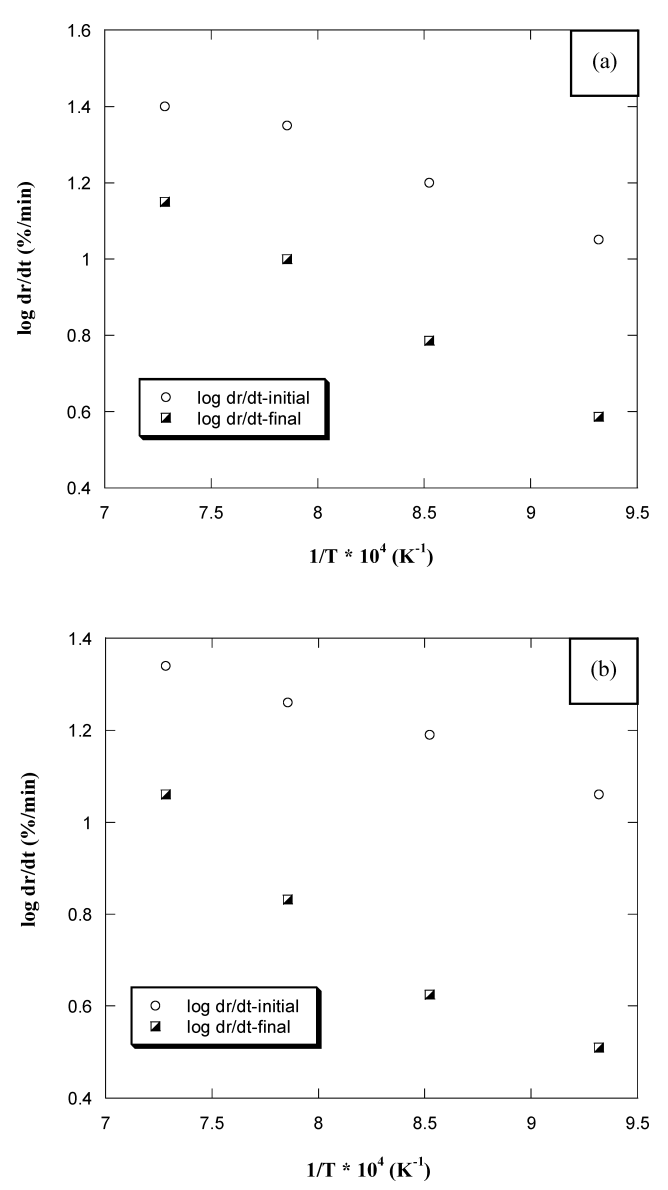

Fig. 8. Arrhenius plots for initial and final reduction stages of (a) $\mathrm{NiFe}_{2} \mathrm{O}_{4}$ and (b) $\mathrm{Ni}_{0.5} \mathrm{Co}_{0.5} \mathrm{Fe}_{2} \mathrm{O}_{4}$ compacts at 800 $1100^{\circ} \mathrm{C}$ with pure hydrogen gas.
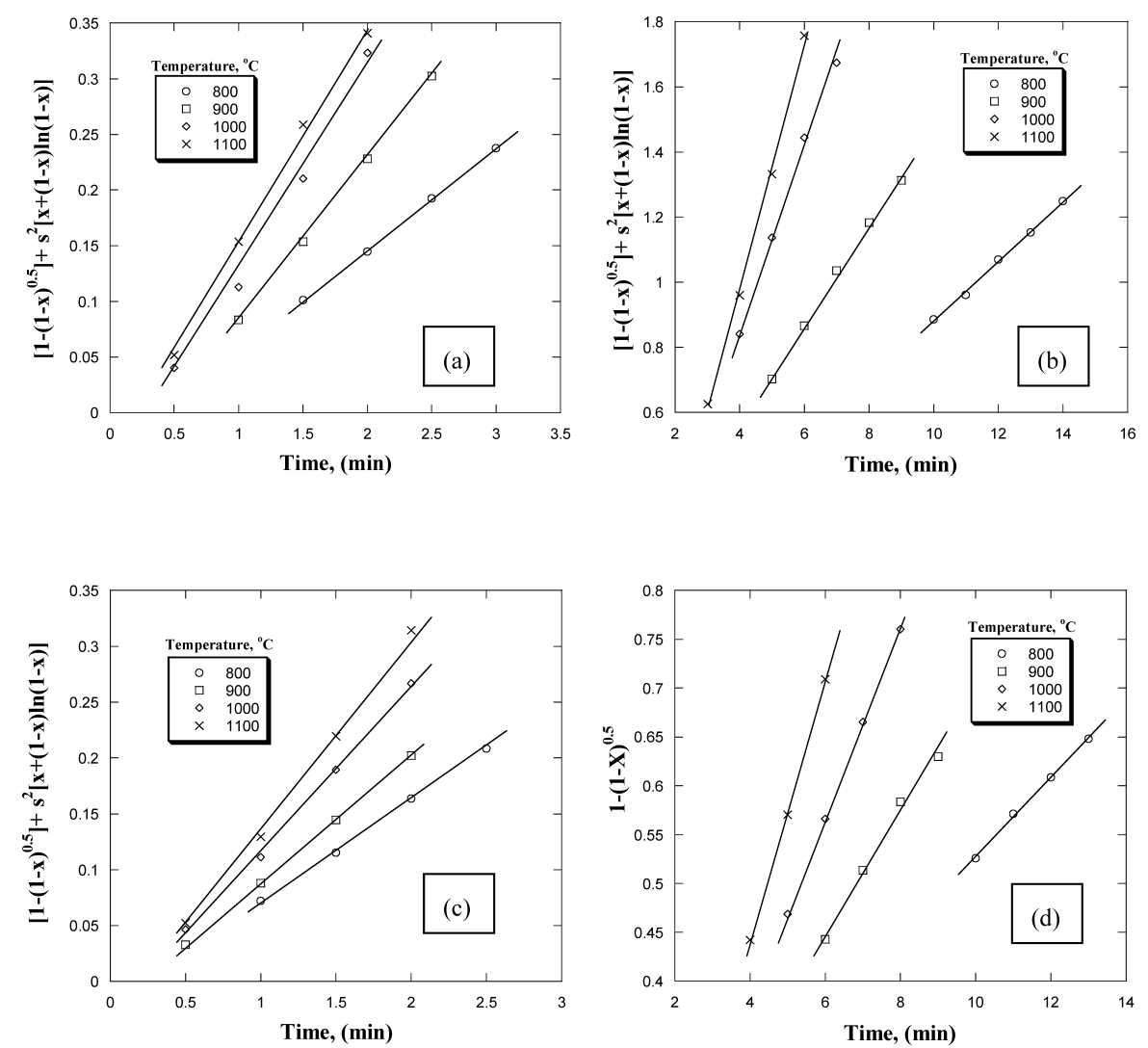

Fig. 9. Applying the mathematical formulation for $(a, b)$ mixed control at the initial and final reduction stages of $\mathrm{NiFe}_{2} \mathrm{O}_{4}$, (c) mixed control at the initial reduction stages of $\mathrm{Ni}_{0.5} \mathrm{Co}_{0.5} \mathrm{Fe}_{2} \mathrm{O}_{4}$ and (d) interfacial chemical reaction at the final reduction stages of $\mathrm{Ni}_{0.5} \mathrm{Co}_{0.5} \mathrm{Fe}_{2} \mathrm{O}_{4}$. 

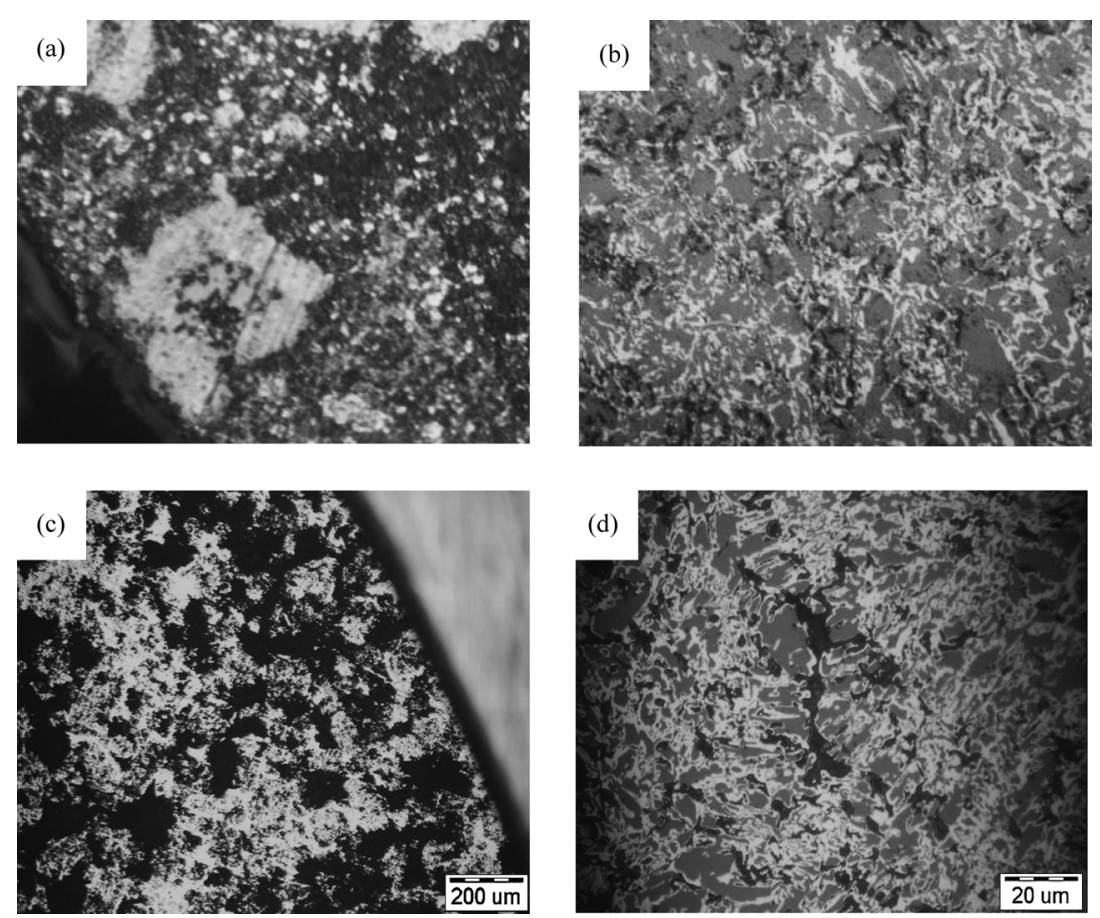

Fig. 10. Microstructure photos of fired compacts partially reduced at $900^{\circ} \mathrm{C}$ with pure hydrogen gas. (a) $25 \%, \mathrm{NiFe}_{2} \mathrm{O}_{4}$ (×100), (b) $80 \%, \mathrm{NiFe}_{2} \mathrm{O}_{4}(\times 1000),\left(\right.$ c) $25 \%, \mathrm{Ni}_{0.5} \mathrm{Co}_{0.5} \mathrm{Fe}_{2} \mathrm{O}_{4}(\times 100)$, (d) $80 \%, \mathrm{Ni}_{0.5} \mathrm{Co}_{0.5} \mathrm{Fe}_{2} \mathrm{O}_{4}(\times 1000)$.

action mechanism.

The microstructure observation for partially reduced $(25$ and $80 \%$ ) samples at $900^{\circ} \mathrm{C}$ is shown in Fig. 10. It is observed that in case of $\mathrm{NiFe}_{2} \mathrm{O}_{4}$, after $25 \%$ reduction extent, lower oxides such as $\mathrm{Fe}_{3} \mathrm{O}_{4}$ and $\mathrm{NiO}$ (gray and dark gray) with metallic grains (bright) are formed in a relatively reasonable porous (black) structure with successful progressing of the reduction (Fig. 10(a)). Also Fig. 10(b) showed that after $80 \%$ reduction extent, the reduction developed with $\mathrm{Fe}-\mathrm{Ni}$ alloy (bright and gray) formation in a relatively porous (black) structure. These observations confirmed that the rate controlling mechanism either at the initial or final reduction stages of $\mathrm{NiFe}_{2} \mathrm{O}_{4}$ is the combined gas diffusion and interfacial chemical reaction mechanisms. On the other hand, in case of $\mathrm{Ni}_{0.5} \mathrm{Co}_{0.5} \mathrm{Fe}_{2} \mathrm{O}_{4}$, after $25 \%$ reduction extent porous structure in homogeneous distribution is observed as shown in Fig. 10(c). However after $80 \%$ reduction extent, the reaction developed with $\mathrm{Fe}-\mathrm{Ni}-\mathrm{Co}$ alloy formation in quite porous (black) and homogeneous structure of metallic alloying element (bright and gray) that facilitate the reducing gas access and successful progressing of the reduction process (Fig. 10(d)). These observations supported that the controlling mechanism in the initial reduction stage is the combined gas diffusion and interfacial chemical reaction mechanisms while the rate controlling mechanism at the final reduction stages of $\mathrm{Ni}_{0.5} \mathrm{Co}_{0.5} \mathrm{Fe}_{2} \mathrm{O}_{4}$ is the interfacial chemical reaction mechanisms.

\section{Conclusions}

This work demonstrated an economic route for synthesis of $\mathrm{Fe}-\mathrm{Ni}$ and $\mathrm{Fe}-\mathrm{Ni}-\mathrm{Co}$ alloys from secondary iron oxide resources (mill scale). Reduction behaviour and kinetics of prepared nickel ferrite and nickel cobalt ferrite in hydrogen atmosphere were investigated.
(1) Using mill scale, nanocrystalline $\mathrm{NiFe}_{2} \mathrm{O}_{4}(37 \mathrm{~nm})$ and $\mathrm{Ni}_{0.5} \mathrm{Co}_{0.5} \mathrm{Fe}_{2} \mathrm{O}_{4}(54.4 \mathrm{~nm})$ powders were synthesized through the classic ceramic route at $1000^{\circ} \mathrm{C}$.

(2) The prepared ferrites were reduced in hydrogen atmosphere at $800-1100^{\circ} \mathrm{C}$. Complete reduction was achieved with synthesis of nanocrystalline $(22 \mathrm{~nm}) \mathrm{Fe}-\mathrm{Ni}$ and $(28 \mathrm{~nm}) \mathrm{Fe}-\mathrm{Ni}-\mathrm{Co}$ alloys.

(3) The reduction rate increased with increasing the reduction temperature in both of the initial and final reduction stages. The apparent activation energy was calculated using Arrhenius equation and indicated that the $\mathrm{NiFe}_{2} \mathrm{O}_{4}$ reduction rate was controlled by combined interfacial chemical reaction and gas diffusion mechanisms. In case of $\mathrm{Ni}_{0.5} \mathrm{Co}_{0.5} \mathrm{Fe}_{2} \mathrm{O}_{4}$ reduction the initial reaction stage is controlled by the combined gas diffusion and interfacial chemical reaction mechanisms with more contribution for the gas diffusion mechanism while the final reaction stages are controlled by the interfacial chemical reaction mechanism.

(4) The concluded mechanisms were confirmed by applying different mathematical models for heterogeneous gas-solid reactions and microstructure observation.

\section{REFERENCES}

1) R. Morales, I. Arvanitidis, Du. Sichen and S. Seetharaman: Metall. Mater. Trans. B, 33B (2002), 589.

2) W. Tremel, H. Kleinke, V. Derstroff and C. Reisner: J. Alloys Compd., 219 (1995), 73.

3) L. T. Romankiw, I. M. Croll and M. Hatzakis: IEEE Trans. Magn., 6 (1970), 579.

4) N. Grobert, M. Mayne, M. Terrones, J. Sloan, R. Kamalakaran, T. Seeger, H. Terrones, N. Ruhle, H. W. Kroto and J. Hutchison: Chem. Commun., 5 (2001), 471.

5) S. Vitta, A. Khuntia, G. Ravikumar and D. Bahadur: J. Magn. Magn. Mater, 320 (2008), 182.

6) H. R. Khan and K. Petrikowski: J. Magn. Mater., 249 (2002), 458.

7) J. Tang, K. Wang, L. Spinu, H. Srikanth, P. Schilling and N. Moelders: J. Magn. Magn. Mater, 249 (2001), 471. 
8) L. Yongsheng, Z. Jincang, Y. Liming, J. Guangqiang, Z. Yufeng, W. Xinyan and C. Shixun: Curr. Appl. Phys., 4 (2004), 455.

9) T. Pikula, D. Oleszak, M. Pekata and E. Jartych: J. Magn. Magn. Mater, 320 (2008), 413.

10) T. Osaka: Electrochem. Acta, 45 (2000), 3311

11) J. H. Zhu, S. J. Geng and D. A. Ballard: Int. J. Hydrogen Energy, 32 (2007), 3682

12) N. H. Phan, M. Schwartz and K. Nobe: J. Appl. Electrochem., 21 (1991), 672.

13) U. Malayoglu and A. Neville: Wear, 259 (2005), 219.

14) M. F. Buchely, J. C. Gutierrez, L. M. Leon and A. Toro: Wear, 259 (2005), 52.

15) L. F. Tong: Trans. Inst. Min. Metall. C, 110 (2001), 123.

16) Y. Li, E. R. Maxey, J. W. Richardson Jr. and B. Ma: J. Mater. Sci. Eng. B, B106 (2004), 6.

17) S. Ebrahimi, C. Ponton and I. harris: J. Mater. Sci., 34 (1999), 45.

18) M. H. Khedr: J. Anal. Appl. Pyrolysis, 73 (2005), 123.

19) M. Bahgat: Min. Proc. Extract Metall., 115 (2006), 195.
20) M. Bahgat, M. Radwan and M. M. Hessien: J. Magn. Magn. Mater., 310 (2007), 107.

21) M. Menzel, V. Sepelak and K. Becker: Solid State Ionics, 141 (2001), 663.

22) K. S. Abdel Halim, M. Bahgat and O. A. Fouad: Mater. Sci. Technol, 22 (2006), 1396.

23) M. Bahgat, M. K. Paek and J. J. Pak: Mater. Trans., 48 (2007), 3132.

24) S. Du, N. S. Srinivasan and L. I. Staffanson: Scand. J. Metall., 17 (1998), 226.

25) B. D. Cullity and S. R. Stock: Elements of X-Ray Diffraction, 3rd ed., Prentice Hall, Englewood Cliffs, NJ, (2001), 167.

26) A. D. Dalvi and W. W. Smetzer: J. Electrochem. Soc., 117 (1970), 1431.

27) M. I. Nasr, A. A. Omar, M. H. Khedr and A. A. El-Geassy: ISIJ Int., 35 (1995), 1043.

28) J. Szekely, J. Evans and H. Y. Sohn: Gas Solid Reactions, Academic Press, New York, (1976), 129. 